\title{
GENDER, EMOTIONAL INTELLIGENCE, APTITUDE AND MATHEMATICAL PERFORMANCE
}

\author{
Presentación Caballero García ${ }^{1 *}$ y Ma Elisabet Cifuentes Sánchez ${ }^{2}$ \\ ${ }^{1}$ Prof. Dr., Camilo José Cela University (Faculty of Education), SPAIN. pcaballero@ucjc.edu \\ ${ }^{2}$ PhD student, Camilo José Cela University (F. of Education) and teacher in secondary education \\ in Castilla La Mancha. SPAIN. elisabet.cs@hotmail.com \\ ${ }^{*}$ Corresponding author
}

\begin{abstract}
The research about the determinants of performance keeps on being educational and social interest. The relationship between emotional intelligence and aptitudes in academic performance is not sufficiently demonstrated, as we do not have conclusive data about the differences of gender in these variables. We also should take into account that we keep finding contradictory data in our literature reviews. In our study we will try to bring some clarity to this issue. Our purpose was on the one hand, to determine whether there are differences by gender in emotional intelligence, aptitudes and mathematical performance and, on the other hand, check if there is a relationship between the emotional intelligence aptitudes and the mathematical performance, and finally, we wanted to determine if the emotional intelligence and aptitudes are predictive variables of the performance in mathematics in students of 6th year of primary education. The sample was made up of a total of 34 students (38\% girls and $62 \%$ boys) of this educational stage, with an average age of 11.5 years. The instruments used were: TMMS-24, BADyG-E3 and qualification lists in the subject of mathematics. Data collection was performed during the class in 4 sessions of about one hour. Descriptive, correlational and predictive data analysis were made. In the results, we describe the sample of students, their emotional intelligence profile, aptitudes and average performance in mathematics; the influence of gender on emotional intelligence, aptitudes and mathematical performance, and predictive value of emotional intelligence and aptitudes in the performance in this area of the curriculum of primary school. The data are discussed because of its importance in explaining the poor performance in mathematics of Spanish students in international tests (PISA, TIMSS), as well as promoting emotional intelligence and differential aptitudes of students as factors of academic success.
\end{abstract}

Keywords: Gender, emotional intelligence, aptitudes, math performance, primary education.

\section{Resumen}

La investigación sobre los determinantes del rendimiento sigue siendo de interés educativo y social. La relación entre la inteligencia emocional y las aptitudes en el rendimiento no está suficientemente demostrada, como tampoco tenemos datos concluyentes de las diferencias por género en estas variables, teniendo en cuenta que seguimos encontrando datos contradictorios en nuestras revisiones bibliográficas. En nuestro estudio trataremos de aportar algo de claridad a esta cuestión. Nuestro propósito fue: por un lado, determinar si existen diferencias por género en inteligencia emocional, aptitudes y rendimiento matemático; por otro, comprobar si existe una relación entre la inteligencia emocional, las aptitudes y el rendimiento matemático; $y$, finalmente, determinar si la inteligencia emocional y las aptitudes son variables 
predictoras del rendimiento en matemáticas de los alumnos de $6^{\circ}$ curso de educación primaria. La muestra estuvo formada por un total de 34 estudiantes (38\% mujeres y $62 \%$ varones) de esta etapa educativa, con un promedio de edad de 11,5 años. Los instrumentos utilizados fueron: el TMMS-24, el BADYG-E3 y la lista de calificaciones en la materia de matemáticas. La recogida de datos se realizó en 4 sesiones de aproximadamente una hora de duración en horario de clase. Se hicieron análisis descriptivos, correlacionales y predictivos de los datos En los resultados obtenidos describimos la muestra de estudiantes, su perfil de IE, las aptitudes y el rendimiento medio en matemáticas, la influencia del género en la relación inteligencia emocional, aptitudes y rendimiento matemático y el valor predictivo de la IE y las aptitudes en el rendimiento en esta materia del currículum de primaria. Los datos se discuten por su importancia en la explicación del bajo rendimiento en matemáticas de los estudiantes españoles en las pruebas internacionales (PISA, TIMMS), así como para la promoción de la inteligencia emocional y las aptitudes diferenciales de los alumnos como factores de éxito académico.

Palabras clave: género, inteligencia emocional, aptitudes, rendimiento matemático, educación primaria.

\section{INTRODUCTION}

The role of emotions in the educational context is one of the lines of investigation that most interest has generated in the past few years, as it is recognized that both the emotional and the social developments are important in the academic performance (Barna \& Brott, 2011).

Coll (1988) underlines that, in contrast to traditional conceptions when learning depended directly on teacher and his methodology, newly developed ideas remark the importance of the role played by the student's processes of thought. In other words, all significant elements affecting the student's mind influences their learning and cover cognitive, affective and motivational aspects. Definitely, it is assumed that the motivational factors can explain a percentage of variance, additional to the already explained by pure cognitive aspects such as the own intelligence or aptitudes of the pupils (Navas, Sarnpascual \& Santed, 2003).

Recent investigations have evaluated the role of aptitudes and emotions from a differential point of view and their academic performance effects on the students. They have used different samples and achieved similar results. In all of these studies the intelligence or differentials aptitudes appear as a predictor moderate/height of student's academic performance. In this line are the work of authors like Chamorro-Premuzic \& Furnham (2006); Deary, Strand, Smith \& Fernandez, (2007); Laidra, Pullman \& Allik, (2007); McMahon, Rose \& Parks, (2004); Ridgell \& Lounsbury (2004); Rolfhus \& Ackerman (1999), etc.

Some research has found positive and significant correlations between emotional intelligence and academic performance (Durén, Extremera, Fernández Berrocal \& Montealbán, 2006; Ferrando et al., 2010; Nasir \& Masrur, 2010; Palomera, Gil-Olarte \& Brackett, 2006). On the contrary, other investigations indicates the low predictive power of intelligence in it (Descals \& Rivas, 2002).

In this sense, Navas et al. (2003) found, in a job that is studying the predictive capacity of intellectual and motivational variables jointly on performance, that motivational variables explain better than intelligence a proportion of additional variance statistically significant in the majority of cases. Recently, Castejón, Gilar \& Pérez (2007), in a research on the acquisition of complex learning, observed that intelligence has a significant influence on the acquisition of the procedural aspects of knowledge, but not in the conceptual aspects.

Traditionally parents, teachers and students have justified school success or failure on the basis of intellectual ability and academic results (good or bad); however, the relationship between these variables does not seem to be so clear, especially when it is possible to observe students with high intellectual abilities and high academic performance, who are unable to solve daily life situations. On the contrary, students with poor performance solve everyday situations satisfactorily and are successful people in life. In this situation, it does not seem easy to identify the keys that determine success or failure of students, beyond intellectual capacity, due to the fact emotional and social aspects have an influence in it (Caballero-García \& Cifuentes, 2014).

Many of our students' problems at school are due to inappropriate emotional education. Therefore, it is important to include the development of emotional competences in the primary school curriculum (Caballero, 2009; Cifuentes, 2014). 
Several studies on emotional intelligence have stated gender differences in the stage of childhood, adolescence and adulthood (Harrod \& Scheer, 2005; Houtmeyers, 2002; Santesso, Reker Schmidt \& Segalowitz, 2006; Young, 2006).

Nowadays, the results obtained by our students in the international evaluation of mathematics are low. Taking into account the importance of the affective factors in the mathematics learning improvements (Gómez-Chacón, 2000), it would be advisable to continue investigating in this line.

For all these reasons, and because there is not sufficiently proven results yet about it, we proposed the need to continue investigating on these issues. We suggest a greater number of longitudinal and cross-sectional studies which will show us the relationships between emotional intelligence and performance and the influence of gender. In our study we will try to bring some clarity to this question.

\section{OBJECTIVES AND HYPOTHESIS}

Our purpose in this research was to find out if there are differences by gender in emotional intelligence, aptitudes and mathematical performance; as well as to check the relationship between the emotional intelligence, aptitudes on a mathematical performance; as well as determine if the emotional intelligence and the aptitudes are predictors variables of mathematical performance in the 6th year of primary education students.

We consider the hypothesis that there is gender significant differences in emotional intelligence, aptitudes and mathematical performance; and there is a positive relationship between emotional intelligence, abilities and performance in mathematics, being both variables able to predict performance in mathematics in the students who have taken part in this research.

\section{METHODOLOGY}

\subsection{Participants}

The sample was selected on a non-random and intentional way. The final group was composed of 34 students in total (38\% women and $62 \%$ males), with an average of 11.5 years old, who were in 6 th year of primary education, in a public school in the province of Albacete (Spain), and that they are in agreement on participating voluntarily in the study.

\subsection{Instruments}

In our research the instruments used were:

- The TMMS-24 (Trait Meta Mood Scale-24) by Fernandez-Berrocal, Extremera \& Ramos (2004), which made possible to measure three dimensions of emotional intelligence (empathy, awareness and selfmanagement). The final scale is composed by 24 items, 8 items by factor. The internal consistency of the subscales in the original validation study was 0.90 for empathy, 0.90 for awareness and 0.86 for self-management. In the present sample we obtained Cronbach's alpha values of $0.87,0.85$, and 0.86 for empathy, awareness and self-management, respectively.

- The BADYG-E3 (Battery of activities for differential and general abilities) of Yuste Hernanz (2009), which was used to know the main students' abilities in the learning process (general intelligence, logical reasoning, verbal analogies, completing sentences, numerical sequences, number problems, logical matrices, completing the empty space in an image with the appropriate geometrical shape, memory for oral storytelling, orthographic visual memory and spotting the differences between similar images) for the learning of the students evaluated. This battery of tests is formed by 288 items, 32 per test, and its reliability is: general intelligence $\alpha=0.95$; logical reasoning $\alpha=0.92$; verbal analogies $\alpha=0.87$; completing sentences $\alpha=0.85$; numerical sequences $\alpha=0.87$; number problems $\alpha$ $=0.84$; logical matrices $\alpha=0.77$; completing the empty space in an image $\alpha=0.74$; memory for oral storytelling $\alpha=0.86$; orthographic visual memory $\alpha=0.98$; differences $\alpha=0.84$.

- Lists of math grades (in first, second, and third evaluation and final grades average of the course) of students of 6 th course analyzed.

\subsection{Data collection procedures}

Data collection was carried out in 4 sessions of 1 hour of duration approximately, one session for each one of the instruments used within the classroom of the group class and in academic hours. The tests were conducted in groups. During the first session, students completed the following activities from the BADyG-E3 I test: VERBAL ANALOGIES (6'), NUMERICAL SEQUENCES (8'), LOGICAL MATRICES (8') and 
COMPLETING SENTENSES (8'). During the second session, they did activities about NUMBER PROBLEMS (9'), COMPLETING THE EMPTY SPACE IN AN IMAGE (5') MEMORY FOR ORAL STORYTELLING /7'), ORTHOGRAPHICAL VISUAL MEMORY (5') and SPOTTING THE DIFFERENCES (3.5'). During the third session, the TMMS-24 test on emotional intelligence was given to the students. They had around thirty minutes to answer this questionnaire. During the fourth session, there was a meeting with the math teacher of $6^{\text {th }}$ course, in order to collect the lists of results from first, second and third term and the list including the students' final average marks. Once all this information had been collected, the different tests and activities were corrected and it was possible to start with the statistical data analysis.

\subsection{Data analysis}

For the data analysis we used the statistical program SPSS 19 , with a $95 \%$ confidence interval and a margin of error of $5 \%$. We carried out a descriptive analysis (frequencies, percentages, averages and standard deviations) with the aim of knowing emotional intelligence, aptitudes and mathematical performance of students in 6th year of primary education. Using a bivariate Pearson correlation, we checked the relationship between emotional intelligence, aptitudes and academic performance in math. To analyze differences of averages by gender, in emotional intelligence, abilities and performance, we used the T Student test and simple analysis of variance (ANOVAS). When differences of mean were significant, we made contrasts of hypothesis (Tukey HSD). Finally, to identify if there are variables for predicting performance in mathematics, we carried out a multiple regression analysis.

\section{RESULTS}

Our students obtained an appropriate level of general emotional intelligence $(\overline{\mathrm{X}}=82,32)$. Of the three studied dimensions, the highest average was "empathy" $(\overline{\mathrm{X}}=28,21)$, followed by "awareness of emotional experience $(\bar{X}=27,62)$ and "emotional self-management" $(\bar{X}=26,74)$.

Regarding differentials aptitudes, the highest average was obtained in the test about spotting the difference and in visual memory $(\bar{X}=23.50)$, and the lowest average in number problems $(\bar{X}=12,26)$, which implies low level of understanding number problems. About performance in mathematics, results were also good, obtaining a $B$ as the average mark of this sample $(\bar{X}=7.03)$. Among the 34 students who took part in this project, the lowest mark was a D (4.80 in the Spanish system) and the highest mark was an A (9.5 in the Spanish system).

Once the Pearson correlation coefficient has been calculated, it seems that it does not exist any lineal positive relationship between total emotional intelligence and students' performance in mathematics $(\mathrm{rP}=0,102$ y $\mathrm{p}=0,566)$. There is not either any relationship between general abilities and performance in mathematics, but there is a relationship between certain differential abilities, with a level of confidence of $99 \%(p<0,01)$ : verbal analogies-performance in mathematics $(r P=0,453, p=0,007)$, numerical sequencesperformance in mathematics $(\mathrm{rP}=0,565, \mathrm{p}=0,000)$, logical matrices- performance in mathematics $(\mathrm{rP}=0,526$, $p=0,001)$, number problems- performance in mathematics $(r P=0,460, p=0,006)$, visual memory-performance in mathematics ( $r P=0,567, p=0,000)$, and spotting the differences-performance in mathematics ( $r P=0,449$, $\mathrm{p}=0,008)$.

With regard to the differences by gender in general emotional intelligence we did not find statistically significant differences $(t=0.354 ; p=0.726)$, nor in awareness $(t=0.937 ; p=0,356)$, or empathy $(t=0,959$; $\mathrm{p}=0.345)$ nor in emotional self-management $(\mathrm{t}=-0,757 ; \mathrm{p}=0.454)$, in spite of the fact that the figure 1 we can see that in boys scores in awareness $(\bar{X}=28,43)$ and empathy $(\bar{X}=28,90)$, are slightly higher than that of the girls who show a somewhat higher emotional self-management $(\bar{X}=27,92)$.

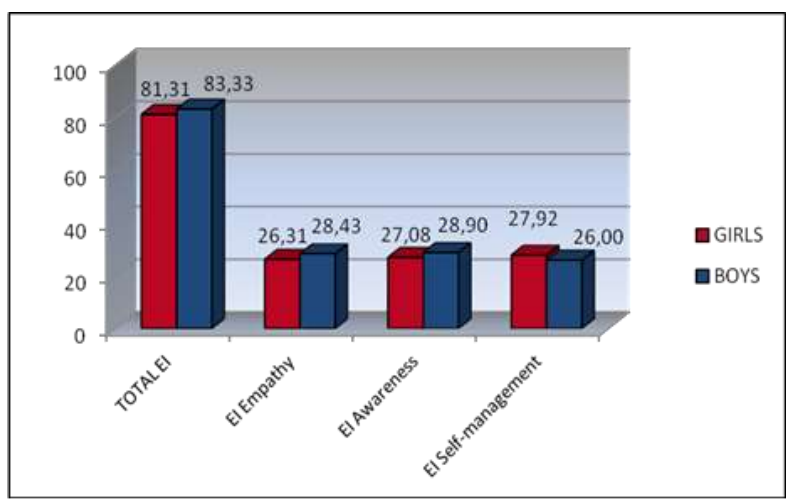

Figure 1. Average level of Emotional Intelligence by gender. 
In relation to differential and general aptitudes of students, we do not find statistically significant differences by gender in any of the abilities assessed with a p-value $>0.05$ in all cases. In Figure 2 we see that the average values obtained in each one of the aptitudes are similar in boys and girls, but the averages of girls are somewhat higher than these of boys, in general, except in orthographic visual memory, where boys have obtained a higher average ( $=24,10$ and $\sigma=6,17)$ that girls ( $=22,54$ and $\sigma=8,53$ ).

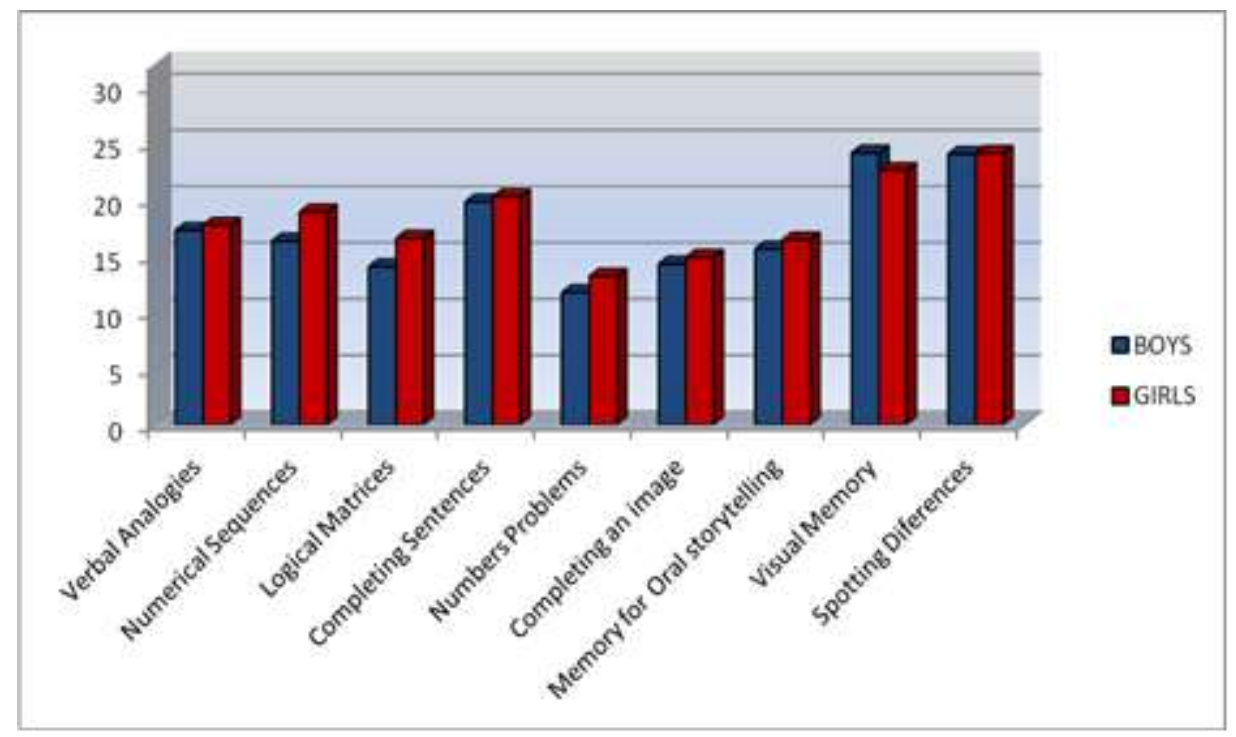

Figure 2. Average of differential and general aptitudes of students by gender.

We have not found significant differences in performance in mathematics, by gender $(t=0.807 ; p=0.426)$. The student's average achievement was "notable" $(B+)$. Boys are the ones closer to that mark $(\bar{X}=7,20$, $\sigma=1,46)$ while girls achieved an average mark of "aprobado" (C) $(\bar{X}=6,75, \sigma=1,8)$.

Finally, regression analysis can lead to the conclusion that $56.1 \%$ of changes in performance in mathematics are due to emotional intelligence, within its dimensions of empathy, awareness of emotional experience and emotional self-management, and due to certain differential abilities such as verbal analogies, numerical sequences, logical matrices, completing sentences, number problems, completing the empty space in an image with the appropriate geometrical shape, memory for oral storytelling, visual memory and spotting the differences between similar images $(R 2=0,561, F=4,521, p=0,01)$. Higher empathy is related to higher performance in mathematics $(B=0,111 ; t=2,143 ; p=0,044)$; Higher marks in verbal analogies are related to higher performance in mathematics $(B=0,142 ; t=2,238 ; p=0,036)$. And better visual memory is also related to higher performance in mathematics $(B=0,097 ; t=2,221 ; p=0,037)$. In this case, the most significant variable in order to explain the dependent variable is "verbal analogies", followed by "visual memory" and "empathy".

\section{CONCLUSIONS AND DISCUSSION}

In conclusion, our study has shown the predictive capacity of the emotional intelligence and some differential aptitudes in mathematical performance, in accordance with findings by other authors as Durén et al. (2006); Ferrando, et al. (2010); Nasir \& Masrur (2010); and Palomera et al. (2006), who discovered positive and significant correlations between emotional intelligence and academic performance.

In particular, it has been shown how the variable of empathy can predict performance in mathematics. In this aspect, the results obtained in this research are similar to those researches which have revealed that the different kinds of affections in the students (emotions, attitudes and beliefs) are key factors in order to understand their mathematics performance, highlighting the important role of beliefs (Frank 1988; Garofalo, 1989; Schoenfeld, 1985, 1992), emotions (Gómez-Chacón, 1997; McLeod, 1992) and attitudes in mathematics (Callejo, 2004; Gairín, 1990).

Moreover, it has been demonstrated that the abilities that has a higher capacity to predict performance in mathematics are verbal analogies and visual memory. In this case, the results presented above are similar to those obtained by Laidra et al. (2007), Rolfus \& Ackerman (1999), who were able to prove that differential abilities are an average/high predictor of students' academic performance. 
With regard to the profile of emotional intelligence, there are no statistically significant differences by gender. These data show the results of several investigations carried out with evidence of self-evaluation report, as the EQ-i of Bar-On (Bar-On, 1997; Bar-On, Granel, Denburg \& Bechara, 2003; Dawda \& Hart, 2000; Devi y Rayulu, 2005), or with TMMS-48 of Mayer \& Salovey (1995) and their versions (Fernández-Berrocal, 2004; Lumley, 2005; Palomera, 2005), where they have not been found clear differences in emotional intelligence between men and women. Nor have we found statistically significant differences by gender, with regard to differential aptitudes of students.

The small size of this sample and its condition of being applied to a particular group of students lead to recommend further research in the future to compensate this limitations and to demonstrate in a more conclusive way the power of these variables to explain the students' mathematical results.

We consider it is very interesting to continue investigating the variables that can influence in mathematical performance, because if we identify them correctly we could initiate preventive and optimizing actions in the mathematical results of our students in the future, and avoid the current school failure in this matter. This situation would make us more competitive in mathematics international tests (PISA, TIMMS).

\section{REFERENCE LIST}

Barna, J. \& Brott, P. (2011). How important is personal-social development to academic achievement? The elementary school conselor's perspective. Professional school counseling, 14 (3), 242-250.

Bar-On, R. (1997). The Bar-On Emotional Quotient Inventory (EQ-i): A test of Emotional Intelligence. Toronto: Multi-Health Systems.

Bar-On, R., Granel, D., Denburg, N., \& Bechara, A. (2003) Exploring the neurological substrate of emotional and social intelligence. ProQuest Medical Library; 28 (8), 1700-1800. Retrieved in http://proquest.umi.com/pqdwb?did=404678131

Caballero, P. A. (2009). Competencias Emocionales: Aprendizaje, desarrollo y evaluación. Madrid, Spain: Universidad Camilo José Cela.

Caballero, P.A. (Dir.) \& Cifuentes, M. E. (2014). La influencia de la inteligencia emocional y las aptitudes en el rendimiento matemático de un grupo de alumnos de $6^{\circ}$ curso de Educación Primaria. Diploma de Estudios Avanzados no publicado. Madrid, Spain: Universidad Camilo José Cela.

Caballero García, P.A. \& Cifuentes, M. E. (2014). Emotional intelligence and aptitude on mathematics achievement: a study with primary students. Actas de la VII Internacional Conference of Education, Research and Innovation (ICERI 2014). Sevilla, Spain, 17-19 de noviembre

Callejo, M.L. \& Vila, A. (2004). Matemáticas para aprender a pensar: El papel de las creencias en la resolución de problemas. Madrid, Spain: Narcea.

Castejón, J.L., Gilar, R. \& Pérez, A. M. (2007). El papel de las habilidades intelectuales generales en la adquisición del conocimiento conceptual y procedimental en una situación de aprendizaje complejo. Revista de Psicología General y Aplicada, 60 (1-2), 149-166.

Chamorro-Premuzic, T. \& Furnham, A. (2006). Self-assessed intelligence and academic performance. Educational Psychology, 26(6), 769-779.

Dawda, D., \& Hart, S. (2000). Assessing emotional intelligence: reliability and validity of the Bar-On Emotional Quotient Inventory (EQ-I) in university students. Personality and Individual Differences, 28 (4), 797-812.

Deary, I. J., Strand, S., Smith, P. \& Fernández, C. (2007). Intelligence and educacional achievement. Intelligence, 35(1), 13-21.

Descals, A. \& Rivas, F. (2002). Capacidades intelectuales y rendimiento escolar de Estudiantes de secundaria: constatación de uma limitada relación. Revista Galego-Portuguesa de Psicoloxía e Educación, 8, 203-214.

Devi, L. U., y Rayulu, T. R. (2005). Levels of emotional intelligence of adolescent boys and girls: A comparative study. Journal of Indian Psychology, 23, 6-11.

Durén, A., Extremera, N., Rey, L., Fernández-Berrocal, P. \& Montealbán, F.M. (2006). Predicting academic 
burnout and engagement in educational settings: Assessing the incremental validity of perceived emotional intelligence beyond perceived stress and general self-efficacy. Psicothema, 18, 158-164.

Extremera, N. \& Fernández-Berrocal, P. (2004). El papel de la Inteligencia Emocional en el Alumnado: Evidencias Empíricas. Revista Electrónica de Investigación Educativa, 6 (2). Retrieved in http://redie.uabc.mx/index.php/redie/article/view/105

Fernández-Berrocal, P., Extremera, N. \& Ramos, (2004). Trait Meta-Mood Scale (TMMS-24). Retrieved in http://www.unh.edu/emotional_intelligence/El\%20Assets/Reprints...Mood\%20Meas\%20and\%20Mood \%20Cong/TMMS24\%20con\%20referencias\%202007.pdf

Ferrando, M., Prieto, M., Alameida, L., Ferrándiz, C., Bermejo, R., López-Pina, J., Hernández, D., Sainz, M., Fernández, M. (2010). Trait Emotional Intelligence and Academic Performance: Controlling for the effects of IQ, personality, and self-concept. Journal of Psychoeducational Assessment. July 29. DOI: $10.1177 / 0734282910374707$.

Frank, M. L. (1988). La resolución de problemas y las creencias matemáticas. Arithmetic Teacher, Enero 1988.

Gairín, J. (1990). Las actitudes en educación. Un estudio sobre la educación matemática. Barcelona, Spain: Boixareu Universitaria.

Garofalo, J. y Lester, F. (1985). Metacognition, cognitive, monitoring and mathematical performance. Journal for Research in Mathematics Education, 16, 163-176.

Gómez-Chacón, I.M. (1997). Procesos de aprendizaje con poblaciones de fracaso escolar en contextos de exclusión social. Las influencias afectivas en el conocimiento de las matemáticas. Tesis doctoral. Madrid, Spain: Universidad Complutense de Madrid.

Gómez-Chacón, I.M. (2000). Matemática emocional. Los afectos en el aprendizaje matemático. Madrid, Spain: Narcea.

Harrod, N. R. \& Scheer, S. D. (2005). An exploration of adolescent emotional intelligence in relation to demographic characteristics. Adolescence (San Diego) an International Quarterly Devoted to the Physiological, Psychological, Psychiatric, Sociological and Educational Aspects of the Second Decade of Human Life, 40 (159), 503-524.

Houtmeyers, K. A. (2002). Attachment relationships and emotional intelligence in preschoolers. Dissertation Abstracts International: Section B: The Sciences and Engineering. 62(10), 4818B.

Laidra, K., Pullman, H. \& Allik, J. (2007). Personality and intelligence as predictors of academic achievement: A cross-sectional study from elementary to secondary school. Personality and Individual Differences, 42(3), 441-451.

Lumley, M. A., Gustavson, B. J., Partridge, R. T., \& Labouvie-Vief, G. (2005). Assessing alexithymia and related emotional ability constructs using multiple methods: interrelationships among measures. Emotion, 5 (3), 329-342.

Mayer, J.D. \& Salovey, P. (1997): What is emotional intelligence? In P. Salovey \& D. Sluyter (Eds). Emotional Development and Emotional Intelligence: Implications for Educators (p. 3-31) New York: Basic Books.

McLeod, D. B. (1992). Research on affect in mathematics education: A reconceptualization. Handbook of Research on Mathematics Teaching and Learning, 575-596.

McMahon, S. D., Rose, D. S. \& Parks, M. (2004). Multiple intelligence and reading achievement: An examination of the Teele Inventory of Multiple Intelligences. Journal of Experimental Education, 73(1), 41-52.

Nasir, M. \& Masrur, R. (2010). An exploration of emocional intelligence of the students of IIUI in relation to gender, age and academic achievement. Bulletin of education and research, 32 (1), 37-51.

Navas, L., Sampascual, G. \& Santed, M. A. (2003). Predicción de las calificaciones de los estudiantes: la capacidad explicativa de la inteligencia general y de la motivación. Revista de Psicología General y Aplicada, 56(2), 225-237.

Palomera, R. (2005). Validez de constructo y desarrollo de la inteligencia emocional. Tesis doctoral no publicada. Madrid, Spain: Universidad Nacional de Educación a Distancia. 
Palomera, R., Gil-Olarte, P. \& Brackett, M. (2006). ¿Se perciben con inteligencia emocional los docentes? Posibles consecuencias sobre la calidad educativa. Retrieved in: http://www.revistaeducacion.mec.es/ re341/re341_28.pdf

Ridgell, S. D. \& Lounsbury, J. W. (2004). Predicting academic success: general intelligence, "Big Five" personality traits, and work drive. College Student Journal, 8(4), 60.

Rofhus, E.L. \& Ackerman, P.L. (1999). Assessing individual differences in knowledge: knowledge, intelligence, and related traits. Journal of Educational Psychology, 91(3), 511-526.

Santesso, D. L., Reker, D. L., Schimdt, L. A., \& Segalowitz, S. J. (2006). Frontal Electroencephalogram Activation Asymmetry, Emotional Intelligence, and Externalizing Behaviors in10-Years-Old Children. Child Psychiatry y Human Development, 36, 311-328.

Schoenfeld, A. H. (1985). Mathematical problem solving. Orlando, FL: Academic Press.

Young, L. D. (200). Parental influences on individual differences in emotional understanding. Dissertation Abstracts International: Section B: The Sciences and Engineering, 66(9), 5128B.

Yuste Hernanz, C. (2009). BADyG-E3 Renovado. Batería de Aptitudes Diferenciales y Generales. Madrid, Spain: CEPE. 